УДК $007: 304: 659.3$

\title{
АУДИТОРІЯ ЯК АВТОР ІНФОРМАЦІЇ: РОЛЬ КОРИСТУВАЧІВ У СТВОРЕННІ КОНТЕНТУ
}

\author{
Тетяна Василюк \\ Львівський національний університет імені Івана Франка, \\ вул. Генерала Чупринки, 49, 79044, Львів, Украӥна, \\ e-mail: tsamonjuk@ukr.net \\ https://orcid.org/0000-0002-4887-233X
}

У статті зосереджено основну увагу на ролі, яку відіграють користувачі у процесі створення медіатекстів. Окреслено форми взаємодії «редакція-читачі» та здійснено аналіз специфіки розміщення контенту від аудиторії на ресурсі, виокремлено способи існування користувацького контенту.

Зосереджено увагу на тому, як взаємодіють медіа зі споживачами інформації в Iнтернеті, способи такої комунікації.

Ключові слова: аудиторія, інформація, контент від аудиторії, медіавиробництво, взаємодія в Мережі.

Інформаційний простір на сучасному етапі розвитку, - в якому присутні і традиційні ЗМК, і інтернет-ЗМК, і соціальні мережі, i блоги, - змінює процеси медіавиробництва та впливає на роботу журналіста.

Роль автора (не-журналіста) набуває популярності серед медіаспоживачів. Як зазначає професор Б. Потятиник, споживачі все більше тяжіють до індивідуальних авторів і голосів, віддалених від інституційних брендів [1]. Адже їхні повідомлення викликають довіру через світоглядний, ціннісний фактор, географічну наближеність до аудиторії, іноді через те, що автор став очевидцем/свідком події.

Образ автора в журналістських текстах та засоби його представлення ставали предметом багатьох досліджень як в Україні, так і за ії межами (Л. Масімова [2], С. Распопова [3]). Типологію авторів повідомлень ЗМК запропонували М. Комова [4], що подає її через персоніфікацію авторів у текстах, та 3. Партико [5], який виділяє групи авторів за типами контенту. На важливій ролі аудиторії у створенні контенту неодноразово наголошували зарубіжні дослідники громадянської журналістики А. Брунс, Д. Гілмор, Г. Дженкінс, Н. Девіс.

Мета статті полягає у тому, щоб дослідити роль користувачів у створенні медіаконтенту, окреслити особливості його функціонування в інформаційному полі, класифікувати користувацький контент за способами його існування, простежити, 3 якою метою медіа використовують контент користувачів.

(C) Василюк Т., 2019

Наукове керівництво і рекомендація до друку - доц. Габор Н. Б. 
Завдання нашого дослідження - окреслити специфіку участі користувачів у створенні контенту, оскільки реципієнти все частіше стають авторами (співавторами) матеріалів, швидко завантажують цікавий контент, у свою чергу ЗМК використовують ці матеріали у роботі.

У виборі мети інформаційної діяльності ЗМК та засобів і методів її досягнення й реалізації, присутнє уявлення про аудиторію - кому і для кого адресована інформація. У процесі дослідження аудиторії певного ЗМК звертають увагу на те, якому каналу найчастіше надається перевага, оцінки контенту, чого очікує аудиторія та якими засобами та способами задовольнити ці потреби.

Власне такі дослідження дають можливість більше та глибше володіти інформацією про свою цільову та потенційну аудиторії і, як результат - корегувати свою редакційну політику, удосконалювати та покращувати роботу ЗМК, аби мати високий критерій довіри від реципієнтів. Важливу роль також відіграє економічний аспект.

Беручи за основу критерій ролі автора у процесі створення матеріалів, дослідниця Інституту журналістики КНУ ім. Т. Шевченка К. Афанасьєва (Горська) поділяє користувацький контент в нових медіа на чотири типи:

- контент створюється користувачем і надалі використовується ЗМК в складі свого медіапродукту після редакційного контролю;

- користувацький контент існує паралельно із професійним медіаконтентом ЗМК (коментарі на сайті);

- контент створюється в результаті спільної творчості працівників ЗМК та користувачів (співавторство);

- контент генерується та розміщується на спеціально створених медіаплатформах ЗМК[6].

Роль професійних журналістів сьогодні змінюється. До безпосередніх обов'язків медійника все частіше додається відбір та подача готової продукції користувачів, опрацювання матеріалів з інших джерел інформації. I це, звісно, впливає як на журналістику в цілому, так і на продукцію зокрема. Свого часу в обов'язки журналістів входило мати коло своїх авторів по районах (робсількорів), заохочувати їх писати про проблеми району чи міста, а потім працювати з текстами, щоб опублікувати. Власне сьогодні до професійних вмінь входить ще до- і післятекстова комунікація 3 читачами, вміння спонукати їх до висловлювання думок, написання ними власних матеріалів (коментарів), провідні медіа займають активну позицію щодо вивчення своєї аудиторії.

Дослідник В. Гвоздєв вважає, що важлива ознака сучасної аудиторії - це креативність. Під креативністю зазвичай розуміється творча, новаторська діяльність [7]. Наприклад, видання «День» пропонує своїм читачам фотоконкурси, де можна заявити про себе як читач-художник (фотомитець).

У сучасних умовах глобалізації інформаційного суспільства аудиторія ЗМК досліджується з наступних позицій. На думку В. Гвоздєва, - не тільки як споживач медіапродуктів зі своїми сформованими звичками, а й як повноправний, незалежний учасник публічної сфери, масово-інформаційних процесів.

Про інтенсивність зростання популярності контенту від користувачів свідчить також історичний розвиток цього типу інформації: на етапі виникнення в Інтернеті все починалося зі створення свого сайту, де розміщувалася інформація, згодом з'яви- 
лася можливість ведення блогу, потім - написання оглядів, оновлення статусу в соцмережах, мікроблогінг, а сьогодні - це розміщення своїх текстів чи думок на різних платформах, інформація різного типу (текст, відео, аудіо, анімації), які пропонує ЗМК.

Отож, можемо підсумувати, що поряд із значною потребою в інформації, масовим іiі споживанням, сьогодні також спостерігається така тенденція як участь аудиторії у роботі традиційних ЗМК та створення і поширення власного, як альтернатива, контенту (матеріали користувачів).

Дослідник Л. Федорчук зазначає, що в XX ст. створювати і розповсюджувати новини могли практично лише журналісти. Сьогодні світові ЗМК втратили монопольне становище. Завдяки стрімкому розвитку технологій інтернетом користуються мільйони людей, які публікують статті, фотографії, аудіозаписи і відеоролики, практично кожен охочий може публічно «самовиражатися», розміщуючи свої матеріали в Інтернеті $[9$, с. 665].

У. Еко прогнозував, що людство поділиться на тих, хто дивиться телевізор, i тих, хто за допомогою персонального комп'ютера самостійно добуватиме та вироблятиме інформацію. Однак, питання тут не тільки в інтелектуальних здібностях, а скоріше, в наявності бажання обирати, яке в сучасному надскладному світі зовсім не обов'язково повинно виникати в усіх випадках [10, с. 81-82].

Сьогодні звичайні пересічні громадяни часто виступають як очевидці та коментатори цікавих подій, навіть стають першими, хто поширив цю ексклюзивну інформацію. Часто аматори-репортери висвітлюють оригінальніше і оперативніше за професіоналів журналістики, опинившись першими на місці події. Але тут $є$ існує ще така реальність: вони не знають всіх нюансів журналістської етики та стандартів (наприклад, вони не зобов'язані бути об'єктивними та ін.). І, звичайно, це все впливає на їхній контент. Провідні ЗМК користуються такою інформацією, коли не мають змоги поїхати на місце надзвичайної події, або не мають інших джерел інформації.

Серед найпоширеніших способів $є$ взаємодія з користувачем через систему коментарів. Перевагою такого типу взаємодії є те, що читачеві не потрібно проходити реєстрацію на сайті. Це можна зробити з іншого джерела, наприклад зі сторінки соціальних мереж, пройшовши ідентифікацію в один чи два кліки. Деякі сайти (приміром, «Українська Правда») створюють свою систему способів інтерактивності: через коментування з акаунта Facebook, де можна сортувати пости за свіжістю чи популярністю.

Інший спосіб - блоги на сайті ЗМК - дають можливість читачам на постійній основі висловлювати свою думку, формувати додатковий контент, який, знову ж таки, може бути коментованим. Створюють «живі щоденники» переважна більшість популярних сайтів українського та закордонного вимірів («Корреспондент.net», «New York Times» та ін.). Наприклад, репортер у Вашингтонському бюро «New York Times» Т. Гіббонс-Нефф опублікував подробиці бою між найманцями РФ і військами США в Сирії. Цю важливу геополітичну проблему прокоментували на ресурсі 342 читачі, висловлюючи свої думки та позиції.

Залучити аудиторію до роботи над сайтом можна і за допомогою конкурсів та спецпроектів.

Ефективно, на мою думку, цим користується телеканал «1+1»: щотижня у ранковому «Сніданку з 1+1» ведучі оголошують тему фотоконкурсу. Глядачі надсилають свої фотографії або на сайт програми, або на сторінку Facebook. За найкраще 
фото отримують приз від телеканалу. Також у цій програмі щодня є вікторини та розіграші, аби привернути більшу частку аудиторії.

Для взаємодії медіа та читачів багато сайтів практикують можливість створення власного профілю для кожного користувача, в якому можна вказати особисті дані, продивлятися залишені коментарі та записи у власному блозі. Користувачі можуть відправляти приватні повідомлення, додавати друзів, вступати в різні спільноти. Система таких профілів набуває масштабів соціальної мережі у рамках певного ЗМК. Наприклад, авторизуватись користувачам дають можливість сайти «Української правди», «Кореспондент.нет».

Взаємодія з аудиторією відбувається й в соціальних мережах. Розміщення посилань у Facebook, Instagram та Twitter не призведе до росту аудиторії. Для цього необхідно залучати журналіста або іншого робітника ЗМК, який би не тільки слідкував за трансляцією матеріалів, але й ретельно відбирав найкращі з них, спонукав до дискусій, відповідав на питання читачів. Більшість медіа мають свої сторінки у найпопулярніших соціальних мережах, куди можна перейти з сайту. Ті ж «1+1», «День». Приміром, «1+1» в соцмережі Instagram постить стріми 3 прямих трансляцій своїх ефірів. На сторінці Facebook газети «День» можна дивитися онлайн-конференції.

Частку аудиторії складають й користувачі мобільних телефонів та смартфонів, через що багато відомих видань вже встигли розробити власні додатки для iPhone, iPad та Android-пристроїв, або принаймні створити мобільну версію власного сайту. Розробляючи згадані версії, сайти враховують технічні можливості та вподобання своїх читачів - 3 якого пристрою для них зручно отримати інформацію. Це значно збільшує обсяг користувачів ресурсу. Наприклад, газета «День» має мобільну версію.

Ці способи взаємодії з аудиторією дозволяють зрозуміти, якої інформації потребує читач і чого очікує від медіа, що потрібно змінювати у роботі сайту, аби утримувати постійних реципієнтів і залучати до співпраці нових.

Проведений аналіз специфіки розміщення контенту від аудиторії на ресурсі «День» за класифікацією К. Афанасьєвої (Горської) допомагає зрозуміти, якими платформами можуть користуватися читачі аби їхній матеріал розмістили на ресурci, як реагують на такий контент ЗМК та інші читачі.

Щоденна всеукраїнська газета «День» дає своїм користувачам багато платформ, де можна висловити свою думку, опублікувати свої матеріали. Читати «День» можна в соціальних мережах Facebook, Twitter, дивитися матеріали на Youtube та підписуватися на канал сайту в Telegram.

Перший тип контенту - користувач-автор. У цьому випадку ЗМІ $\epsilon$ не лише засобом масової інформації, але й каналом участі користувачів у соціальному житті суспільства. Наприклад, газета «День» має гіперактивну вкладку на сайті «Повідомте про новину», де користувач може безпосередньо розповісти за телефоном до редакції, або ж написати на зазначений e-mail, або ж написати текст (можна додавати й фото) та завантажити на сервер сайту. Відразу є клік на соцмережі Facebook, Twitter.

Другий тип контенту - користувач-співавтор. Користувацький матеріал існує паралельно з матеріалом ЗМІ. На сьогодні система коментарів є найбільш потужною платформою для формування публічної дискусії. Наприклад, «День» дає можливість розміщувати свій коментар під кожним повідомленням. Читачі коментують матеріал, при цьому теж мають коментарі на свій допис від інших користувачів (іно- 
ді відбувається онлайн-дискусія між коментаторами). Багато сайтів пропонують авторизацію, аби коментарі (пости) були персоналізованими.

Третій тип контенту - колективна творчість. Спільна творчість журналіста та авторів часто проводиться тоді, коли планується з'ясувати думку щодо того чи іншого важливого суспільного питання. Яскравими прикладами буде матеріал, який створений на основі опитувань, розміщених раніше на ресурсі. Отримані результати будуть підтвердженням зацікавленості до теми у соціумі , показує широке коло думок та поглядів.

На сайті «Дня» періодично проводяться різні тематичні опитування, де може кожен проголосувати за власний варіант з приводу певного запитання, можна переглянути результати того чи іншого опитування.

Четвертий тип контенту - традиційною практикою сайтів провідних медіа $€$ ведення авторських блогів. Більшою мірою сайти ЗМК не мають вплив на конкретне наповнення «живого щоденника» автора. Втім авторитетні редакції все ж до певної межі регулюють ці записи. Здебільшого серед правил ведення блогів та коментарів до них є заборона використання нецензурної лексики, образливих висловів, погрозливих заяв та ін. У «Дні» періодично наповнюються авторські блоги, де є можливість обговорення та коментування теми публікації.

Медіатренер, екс-керівник інтернет-проекту «Коло» І. Фанта зазначає, що «... інформацію шукати не самотужки, а звертатися до тих, для кого ми пишемо матеріали. I коли ми спілкуємося з ними, щось придумуємо самі, потім складаємо це все у великий пазл, який і називається інтегрованим сторітелінгом» [12].

Проаналізувавши специфіку розміщення та використання користувацького контенту у «Дні», можна підсумувати: користувацький матеріал береться до уваги, до опрацювання, використовується як джерело інформації (на основі опитування), редакція постійно знаходить нові підходи до його використання, стратегії вивчення своєї аудиторії, дописи від читачів спонукають до створення додаткових сервісів (у рубриці «Музеї онлайн» $є$ послуга віртуальної екскурсії, також $є$ ще інтелектуальна карта України - довідковий маршрут визначними містами). Власне, такі сервіси присутні лише на гіперлокальних медіа.

Варто ще наголосити, для чого потрібні матеріали від читачів для редакції. Це, насамперед, додатковий контент, матеріали, які зазвичай є безкоштовними або дешевими. А ще - це додаткова реклама, піар видання, адже аудиторія, яка створює та розміщує матеріали, поділиться про це 3 друзями, дописи у соцмережах будуть перепощувати і робитимуть підписку нові читачі. Також різні способи взаємодії $з$ аудиторією дають можливість для ЗМК стати більш важливішим для свого реципієнта, ближчим у поглядах та уподобаннях, стати медіа, яке задовольняє його потреби.

\section{Висновки}

У цьому дослідженні ми з'ясували, що в сучасному медіапросторі аудиторія стає активним суб'єктом у роботі ЗМК, підвищується рівень креативності та оригінальності, ексклюзивності повідомлень від читачів, глядачів, слухачів, онлайн-користувачів.

На прикладі ресурсів «1+1», «День», «Українська Правда» дослідили способи взаємодії ЗМК з користувачами (система коментарів, блоги, конкурси та спецпроекти, створення власного профілю на ресурсі видання, сторінки ЗМК у соціальних мережах). 
Проаналізували специфіку розміщення контенту від аудиторії на ресурсі «День», виокремили способи існування користувацького контенту: користувач-автор, користувач-співавтор, колективна творчість.

Видання намагаються використовувати користувацький контент, залучати аудиторію до написання, опрацьовувати та використовувати дописи на ресурсі, стимулювати користувачів до співпраці, аби розвиватися далі і збільшувати коло своїх читачів, бути популярним і затребуваним, мати, завдяки цьому контенту, належний рівень довіри своєї аудиторії.

\section{REFERENCES}

1. Потятиник Б. Медіа : ключі до розуміння. Серія : Медіакритика / Б. Потятиник. Львів : ПАІС, 2004. 312 с.

2. Масімова Л. Способи представлення авторів журнального контенту // Ученые записки Таврического национального университета им. В. И. Вернадского. Серия «Филология. Социальные коммуникации» / Л. Масімова. Том 24 (63). 2011. №4. Часть 1. С. 362-366.

3. Распопова С. Автор как реальный человек и образ-автор в медиатексте / С. Распопова // Вопросы теории и практики журналистики. 2015. Т. 4. №2. С. 149-158.

4. Комова М. Типологія авторів повідомлень у засобах масової комунікації / М. Комова // Світові стандарти сучасної журналістики: збірник наукових праць. Черкаси : Видав. Чабатенко Ю., 2010. С. 359-362.

5. Партико 3. Загальне редагування: нормативні основи : навч. посіб. / 3. Партико. Львів : Афіша, 2001. 416 с.

6. Афанасьева (Горська) К. Користувацький контент : зона відповідальності ЗМІ чи аудиторії? // Держава та регіони. 3., 2014. Вип. 1-2. - Режим доступу до ресурcy: http://www.irbis-nbuv.gov.ua/cgi-bin/irbis_nbuv/cgiirbis_64.exe?I21DBN=LINK\& $\mathrm{P} 21 \mathrm{DBN}=\mathrm{UJRN} \& Z 21 \mathrm{ID}=\& \mathrm{~S} 21 \mathrm{REF}=10 \& \mathrm{~S} 21 \mathrm{CNR}=20 \& \mathrm{~S} 21 \mathrm{STN}=1 \& \mathrm{~S} 21 \mathrm{FMT}=\mathrm{ASP}$ meta\&C21COM=S\&2_S21P03 $=$ FILA $=\& 2 \_S 21 S T R=$ drgn_2014_1-2_18

7. Гвоздєв В. Креативність як ознака сучасної медіа-території [Електронний ресурс] / В. Гвоздєв - Режим доступу до ресурсу: http://prima.franko.lviv.ua/faculty/jur/ vypusk7/n13/tv13-26.pdf

8. Короченский А. Журналистика после СССР: два десятилетия обретений и утрат / А. Короченский // Журналистика постсоветских республик: 20 лет спустя : сб. трудов Междунар. науч.-практ. конф.; под ред. А. Короченского и М. Казак. Белгород : Константа, 2012. С. 8-11.

9. Федорчук Л. Вплив «народної журналістики» на розвиток традиційних ЗМІ / Л. Федорчук // Гілея : наук. вісник : зб. наук. праць / Нац. пед. ун-т ім. М. Драгоманова, Українська АН. К. : Вид-во НПУ ім. М. Драгоманова, 2011. Вип. 44 (№2). C. 665-671.

10. Калмыков А. Интерактивная гипертекстовая журналистика в системе отечественных СМИ / А. Калмыков. М. : Ин-т повышения квалификации работников телевидения и радиовещания, 2009. 284 с.

11. Сущук М. Як медіа взаємодіють з аудиторією в Інтернеті [Електронний ресурс] / М. Сущук. - Режим доступу до ресурсу: http:/watcher.com.ua/2011/05/13/yak-mediavzayemodiyut-z-audytoriyeyu-v-interneti 
12. Дорош М. Контент від аудиторії: чи потрібен цей головний біль? [Електронний ресурс] / М. Дорош. - Режим доступу до ресурсу: https://ms.detector.media/ mediaprosvita/how_to/kontent_vid_auditorii_chi_potriben_tsey_golovniy_bil

\title{
AUDIENCE AS THE AUTHOR OF INFORMATION: THE ROLE OF USERS IN CREATING CONTENT
}

\author{
Tetiana Vasyliuk \\ Ivan Franko National University of Lviv, \\ Generala Chuprynky Str., 49, 79044, Lviv, Ukraine \\ e-mail: tsamonjuk@ukr.net \\ https://orcid.org/0000-0002-4887-233X
}

The article focuses on the role that users play in creating materials. We have analyzed which forms of interaction are used by editors between readers.

We have focused on the interaction of media with users on the Internet, ways of such information.

The information space of the current stage of development changes the processes of media production and adjusts the work of the journalist. The active participation of the audience on the Internet has become the cause of research, it's behavior, ethics and preferences.

The role of the author becomes widespread without the personal or automated nature of the dissemination of information. Messages from users are trusted due to philosophical value factor, geographic proximity to the audience.

We take info account the consciousness and behavior of readers/listeners during the consumption of information, the criteria for selecting materials on the resource during the study of the audience.

In fact, such studies make it possible to have more and deeper knowledge about their potential audience. The study corrects their editorial policies, improve the work of the media.

Media corporations often use simple and inexpensive methods of obtaining and disseminating information. Journalists prepare information without leaving their workplace. They do not overlook the option of rewriting materials from other media.

The modern media audience is explored and studied, new terminology and spheres of research are emerging.

Key words: audience, information, content from the audience, media production, network interaction. 